\section{Synthesis of Non-Steroidal Estrogen Receptor Antagonists R1128 A, B, C, and $D$ via an Oxazoline-Promoted Iterative ortho-Lithiation Strategy}

\author{
Tsutomu Fukuda, Koichiro Fukushima, \\ Susumu Sanai, and Masatomo Iwao* \\ Division of Chemistry and Materials Science, Graduate \\ School of Engineering, Nagasaki University, \\ 1-14 Bunkyo-machi, Nagasaki 852-8521 \\ Received August 12, 2011 \\ E-mail: iwao@nagasaki-u.ac.jp
}

A concise total synthesis of non-steroidal estrogen receptor antagonists R1128 A-D (1a-1d) has been achieved using iterative ortho-lithiation of 2-(4-methoxyphenyl)-4,4dimethyloxazoline (3) as the key reaction.

Tamoxifen, a non-steroidal estrogen receptor antagonist, has been employed in the chemotherapy of estrogen receptor positive breast cancer. ${ }^{1}$ However, long-term administration of tamoxifen frequently results in development of tumor resistance to this drug. Therefore, a variety of new types of estrogen receptor modulators have been investigated. ${ }^{2}$ In 1993, Hori et al. of Fujisawa Pharmaceutical Co. reported the isolation of novel non-steroidal estrogen receptor antagonists named R1128 A, B, C, and D (1a-1d) from the cultured broth of Streptomyces sp. No. $1128 .^{3}$ These compounds possess a common structural motif of 8-alkyl-1,3,6-trihydroxyanthraquinone (Figure 1). They exhibited varying degrees of estrogen receptor binding activities depending on the length of alkyl groups at the 8-position. Moreover, R1128 B showed potent antitumor activity against estrogen receptor positive human mammary adenocarcinoma MCF-7 xenografted in nude mice. Despite these impressive biological activities, the synthesis of 1a-1d has not been reported. In this paper, we describe the first and concise total synthesis of $\mathbf{1 a - 1 d}$.

Snieckus and co-workers reported the regioselective and efficient synthesis of a variety of anthraquinone natural products using the directed ortho-lithiation of $\mathrm{N}, \mathrm{N}$-diethylbenzamides as the key reaction. ${ }^{4}$ This strategy was extended to the synthesis of peri-methylanthraquinone natural products such as erythrolaccin and deoxyerythrolaccin. ${ }^{5}$ In this synthesis, a silicon-protection protocol has been developed to avoid the preferential lateral lithiation of $N, N$-diethyl-omethylbenzamides. ${ }^{6}$ On the other hand, we discovered that the selective ortho-lithiation of 4,4-dimethyl-2-(o-tolyl)oxazolines can be achieved under kinetically controlled conditions without protecting the thermodynamically more acidic lateral methyl group. ${ }^{7}$ This novel reaction was successfully applied to

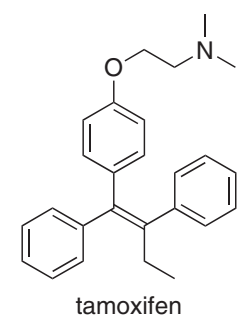<smiles>[R]c1cc(O)cc2c1C(=O)c1c(O)cc(O)cc1C2=O</smiles>

$\mathrm{R} 1128 \mathrm{~A}$ (1a): $\mathrm{R}=\mathrm{CH}_{2} \mathrm{CH}_{2} \mathrm{CH}_{3}$

R1128 B (1b): $\mathrm{R}=\mathrm{CH}_{2} \mathrm{CH}_{2} \mathrm{CH}_{2} \mathrm{CH}_{3}$ $\mathrm{R} 1128 \mathrm{C}$ (1c): $\mathrm{R}=\mathrm{CH}_{2} \mathrm{CH}_{2} \mathrm{CH}\left(\mathrm{CH}_{3}\right)_{2}$

R1128 D (1d): $\mathrm{R}=\mathrm{CH}_{2} \mathrm{CH}_{2} \mathrm{CH}_{2} \mathrm{CH}_{2} \mathrm{CH}_{3}$

Figure 1. Tamoxifen and R1128 A-D.<smiles>[R]c1cc(OC)cc(C2OC(=O)c3c([R])cc(OC)cc32)c1</smiles>

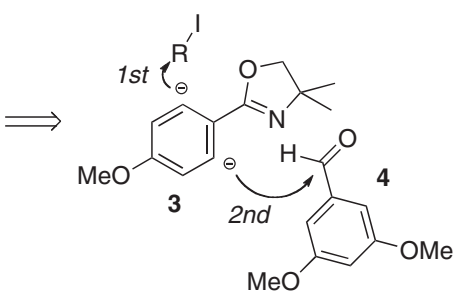

Scheme 1. Retrosynthetic analysis of R1128s 1.

a short synthesis of 3,4-dihydroisocoumarin natural products. ${ }^{8}$ On the basis of these results, we designed a concise synthesis of R1128s 1 (Scheme 1). As is expected from previous studies, ${ }^{4,5} \mathbf{1}$ can be derived from 7-alkylphthalides 2 . The construction of $\mathbf{2}$ will be efficiently achieved via iterative ortho-lithiation $^{6}$ of 2-(4-methoxyphenyl)-4,4-dimethyloxazoline (3): 1) the initial ortho-lithiation of $\mathbf{3}$ followed by alkylation with iodoalkane, 2) the second ortho-lithiation of the alkylated products followed by addition to 3,5-dimethoxybenzaldehyde (4).

The total synthesis of R1128 A-D (1a-1d) following this idea is depicted in Scheme 2. ortho-Lithiation of the oxazoline 3 with sec-BuLi (1.2 equiv) in THF at $-78^{\circ} \mathrm{C}$ followed by treatment with appropriate iodoalkanes gave the ortho-alkylated products $\mathbf{5 a - 5 d}$ in $79-86 \%$ yields. ${ }^{9}$ These compounds were lithiated again with sec-BuLi (1.2 equiv) in THF at $-78^{\circ} \mathrm{C}$ and treated with 3,5-dimethoxybenzaldehyde (4). Crude addition products were not isolated but subjected to trifluoroacetic acid (TFA)-mediated lactonization ${ }^{10}$ to give 7-alkylphthalides $\mathbf{2 a - 2 d}$ in 73-90\% yields. It is noteworthy that the 3,4-dihydroisocoumarins derived from the laterally lithiated species were not isolated in these reactions. Thus, the lithiations of $\mathbf{5 a}-\mathbf{5} \mathbf{d}$ under sec-BuLi-THF conditions are highly 


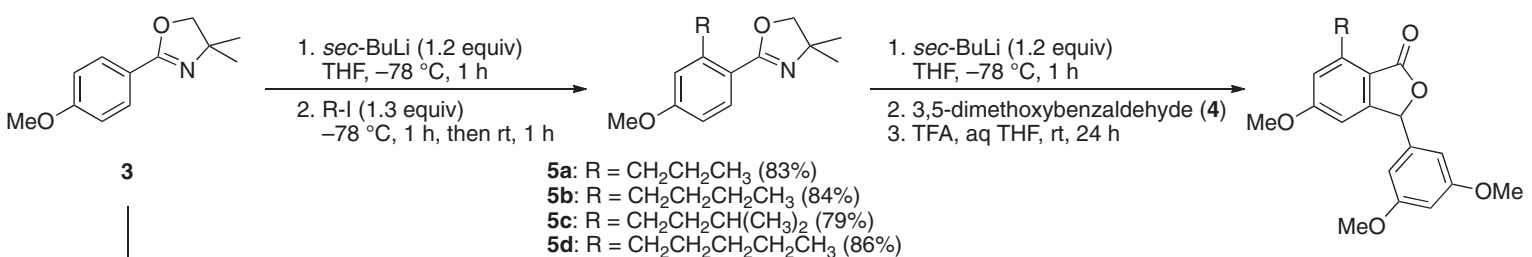

One-pot synthesis without isolation of $5 a-5 d$

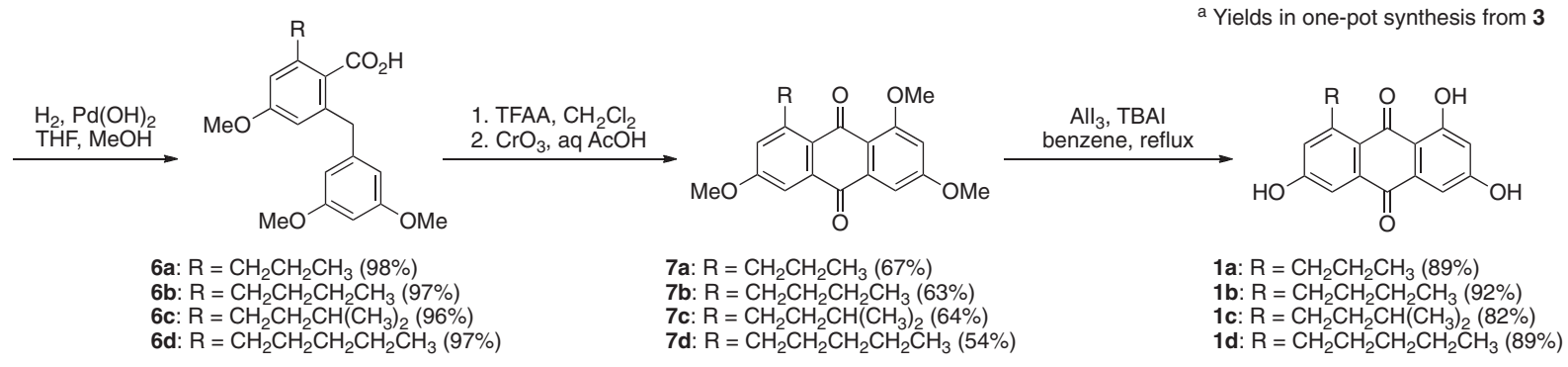

Scheme 2. Total synthesis of R1128 A-D (1a-1d).

ortho-selective. More efficient transformation of $\mathbf{3}$ to $\mathbf{2}$ can be achieved by a one-pot reaction without isolation of the intermediates 5. In this manner, phthalides $\mathbf{2 a - 2 d}$ were obtained after TFA-mediated lactonization in $66-71 \%$ yields. The yields are comparable to those of the two-pot reactions (61-77\%).

Conversion of the phthalides $\mathbf{2 a - 2 d}$ to R1128 A-D (1a-1d) was efficiently achieved in three steps. ${ }^{4,5}$ Hydrogenolysis of the phthalide ring of $\mathbf{2 a - 2 d}$ using Pearlman's catalyst ${ }^{11}$ gave $o$-benzylbenzoic acids $\mathbf{6 a - 6 d}$ in nearly quantitative yields. Friedel-Crafts cyclization of $\mathbf{6 a - 6 d}$ using trifluoroacetic anhydride (TFAA) followed by oxidation with chromium trioxide gave anthraquinones $\mathbf{7 a - 7 d}$ in moderate yields. Final deprotection of all the methyl groups with aluminum triiodide ${ }^{12}$ in refluxing benzene gave R1128 A-D (1a-1d) in good yields. An attempted deprotection of $7 \mathbf{a}$ with boron tribromide produced a complex mixture of partially demethylated anthraquinones. ${ }^{1} \mathrm{H}$ and ${ }^{13} \mathrm{C}$ NMR spectra of $\mathbf{1 a - 1 d}$ thus synthesized were shown to be identical with those reported for the natural products. $^{3 \mathrm{~b}}$

In conclusion, we have achieved a concise total synthesis of R1128 A-D (1a-1d) using oxazoline-promoted iterative ortholithiation of $\mathbf{3}$ as the key reaction. The average total yield is approximately $36 \%$. The synthetic route described herein is suitable to provide R1128 analogues with a variety of perialkyl groups for structure-activity relationship studies.

\section{Experimental}

Synthesis of ortho-Alkyloxazolines 5. Typical Procedure. Under an argon atmosphere, a cyclohexane- $n$-hexane solution of sec-BuLi $(1.02 \mathrm{M}, 6.00 \mathrm{mmol})$ was added dropwise to a solution of $\mathbf{3}^{13}(1.03 \mathrm{~g}, 5.00 \mathrm{mmol})$ in THF $(50 \mathrm{~mL})$ at $-78^{\circ} \mathrm{C}$. After being stirred for $1 \mathrm{~h}$, an appropriate iodoalkane $(6.50$ mmol) was added as a neat liquid. After being stirred for $1 \mathrm{~h}$ at $-78^{\circ} \mathrm{C}$, the reaction mixture was allowed to warm to room temperature and stirred for an additional $1 \mathrm{~h}$. The mixture was quenched with saturated aqueous $\mathrm{NH}_{4} \mathrm{Cl}$ and evaporated. The products were extracted with diethyl ether, and the extract was washed with brine, dried over $\mathrm{Na}_{2} \mathrm{SO}_{4}$, and evaporated. The residue was purified by flash chromatography over Silica Gel $60 \mathrm{~N}$ (hexane-ethyl acetate $=3: 1$ ) to give 5. Physical and spectroscopic data of $\mathbf{5}$ are shown in Supporting Information.

Synthesis of 7-Alkylphthalides 2. Typical Procedure. Under an argon atmosphere, a cyclohexane- $n$-hexane solution of sec-BuLi $(1.04 \mathrm{M}, 1.2 \mathrm{mmol})$ was added dropwise to a solution of $5(1.00 \mathrm{mmol})$ in THF $(10 \mathrm{~mL})$ at $-78^{\circ} \mathrm{C}$. After being stirred for $1 \mathrm{~h}$, a solution of 3,5-dimethoxybenzaldehyde (4) $(216 \mathrm{mg}, 1.3 \mathrm{mmol})$ in THF $(3 \mathrm{~mL})$ was added dropwise. After being stirred for $1 \mathrm{~h}$, the mixture was quenched with water, allowed to warm to room temperature, and evaporated. The products were extracted with diethyl ether and the extract was washed with brine, dried over $\mathrm{Na}_{2} \mathrm{SO}_{4}$, and evaporated. The residue was dissolved in $10 \mathrm{~mL}$ of a mixed solvent (THF$\left.\mathrm{H}_{2} \mathrm{O}-\mathrm{TFA}=10: 1.5: 0.5\right)$ at room temperature. After being stirred for $24 \mathrm{~h}$, the mixture was quenched with saturated aqueous $\mathrm{NaHCO}_{3}$ and evaporated. The products were extracted with diethyl ether and the extract was washed with water and brine, dried over $\mathrm{Na}_{2} \mathrm{SO}_{4}$, and evaporated. The residue was purified by flash chromatography over Silica Gel 60N (hexaneethyl acetate $=3: 1$ ) to give 2 . Physical and spectroscopic data of $\mathbf{2}$ are shown in Supporting Information.

One-Pot Synthesis of 7-Alkylphthalides 2. Typical Procedure. Under an argon atmosphere, a cyclohexane- $n$-hexane solution of sec-BuLi $(0.923-1.00 \mathrm{M}, 1.47 \mathrm{mmol})$ was added dropwise to a solution of $3(0.977 \mathrm{mmol})$ in THF $(10 \mathrm{~mL})$ at $-78^{\circ} \mathrm{C}$. After being stirred for $1 \mathrm{~h}$, an appropriate iodoalkane (1.66 mmol) was added as a neat liquid. After being stirred for $1 \mathrm{~h}$ at $-78^{\circ} \mathrm{C}$, the reaction mixture was allowed to warm to room temperature, stirred for an additional $1 \mathrm{~h}$, and recooled to $-78^{\circ} \mathrm{C}$. A cyclohexane- $n$-hexane solution of sec-BuLi (0.923$1.00 \mathrm{M}, 1.66 \mathrm{mmol})$ was added dropwise to the reaction mixture at $-78^{\circ} \mathrm{C}$. After being stirred for $1 \mathrm{~h}$, a solution of 3,5-dimethoxybenzaldehyde (4) $(276 \mathrm{mg}, 1.66 \mathrm{mmol})$ in THF $(3 \mathrm{~mL})$ was added dropwise. After being stirred for $1 \mathrm{~h}$, the mixture was quenched with water, allowed to warm to room temperature, and evaporated. The products were extracted with 
diethyl ether and the extract was washed with brine, dried over $\mathrm{Na}_{2} \mathrm{SO}_{4}$, and evaporated. The residue was dissolved in $10 \mathrm{~mL}$ of a mixed solvent $\left(\mathrm{THF}-\mathrm{H}_{2} \mathrm{O}-\mathrm{TFA}=10: 1.5: 0.5\right)$ at room temperature. After being stirred for $24 \mathrm{~h}$, the mixture was quenched with saturated aqueous $\mathrm{NaHCO}_{3}$ and evaporated. The products were extracted with diethyl ether and the extract was washed with brine, dried over $\mathrm{Na}_{2} \mathrm{SO}_{4}$, and evaporated. The residue was purified successively by flash chromatography over Silica Gel $60 \mathrm{~N}$ (hexane-ethyl acetate $=7: 1$ ) and flash chromatography over Silica Gel $60 \mathrm{~N}$ (toluene-ethyl acetate $=20: 1$ ) to give 2 .

Synthesis of Benzylbenzoic Acids 6. Typical Procedure. Under a hydrogen atmosphere, a mixture of phthalide $2(1.50 \mathrm{mmol})$, Pearlman's catalyst $(514 \mathrm{mg})$, THF $(7.5 \mathrm{~mL})$, and methanol $(7.5 \mathrm{~mL})$ was vigorously stirred overnight at room temperature. The mixture was passed through a pad of Celite and the filtrate was evaporated. The residue was purified by column chromatography over Silica Gel $60 \mathrm{~N}$ (hexane-ethyl acetate $=2: 1$ ) to give 6 . Physical and spectroscopic data of $\mathbf{6}$ are shown in Supporting Information.

Synthesis of Anthraquinones 7. Typical Procedure. Under an argon atmosphere, trifluoroacetic anhydride (1.99 mmol) was added as a neat liquid to a solution of benzoic acid $6(0.302 \mathrm{mmol})$ in dichloromethane $(12.9 \mathrm{~mL})$ at $0{ }^{\circ} \mathrm{C}$. The reaction mixture was allowed to warm to room temperature and stirred for $5 \mathrm{~h}$. The mixture was quenched with methanol and the solvent was evaporated. To the residue was added saturated aqueous $\mathrm{NaHCO}_{3}$ and the mixture was extracted with dichloromethane. The extract was dried over $\mathrm{Na}_{2} \mathrm{SO}_{4}$ and evaporated.

To the crude product was added a solution of $\mathrm{CrO}_{3}(0.338$ $\mathrm{mmol}$ ) and water (several drops) in acetic acid $(7.6 \mathrm{~mL})$. After being stirred for $3.5 \mathrm{~h}$ at room temperature, the mixture was evaporated. To the residue was added saturated aqueous $\mathrm{NaHCO}_{3}$ and the mixture was extracted with dichloromethane. The extract was passed through a pad of Celite. The filtrate was dried over $\mathrm{Na}_{2} \mathrm{SO}_{4}$ and evaporated. The residue was purified by column chromatography over Silica Gel $60 \mathrm{~N}$ to give 7 . Physical and spectroscopic data of $\mathbf{7}$ are shown in Supporting Information.

Synthesis of R1128s 1. Typical Procedure. Under an argon atmosphere, a mixture of aluminum (foil, $1.14 \mathrm{mmol}$ ), iodine $(0.859 \mathrm{mmol})$, and benzene $(5.0 \mathrm{~mL})$ was refluxed for $1.5 \mathrm{~h}$ and then cooled to room temperature. To the suspension was added a solution of anthraquinone $7(84.7 \mu \mathrm{mol})$ and tetrabutylammonium iodide $(4.9 \mu \mathrm{mol})$ in benzene $(3 \mathrm{~mL})$. After being refluxed for $12 \mathrm{~h}$, the mixture was cooled to room temperature and quenched with water. The product was acidified with $2 \mathrm{M}$ aqueous $\mathrm{HCl}$ and extracted with ethyl acetate. The organic phase was extracted with $2 \mathrm{M}$ aqueous $\mathrm{NaOH}$ and the extract was washed with ethyl acetate and acidified with concentrated $\mathrm{HCl}$. The product was re-extracted with ethyl acetate and the extract was dried over $\mathrm{Na}_{2} \mathrm{SO}_{4}$ and evaporated. The residue was purified by column chromatography over Silica Gel $60 \mathrm{~N}$ (dichloromethane-ethyl acetate = 10:1) to give 1. Physical and spectroscopic data of $\mathbf{1}$ are shown in Supporting Information.

\section{Supporting Information}

Physical and spectroscopic data including ${ }^{1} \mathrm{H}$ and ${ }^{13} \mathrm{CNMR}$ spectra of all compounds synthesized in this work. This material is available free of charge on the web at http:// www.csj.jp/journals/bcsj/.

\section{References}

1 a) S. Litherland, I. M. Jackson, Cancer Treat. Rev. 1988, 15, 183. b) M. Clemons, S. Danson, A. Howell, Cancer Treat. Rev. 2002, $28,165$.

2 V. C. Jordan, A. M. H. Brodie, Steroids 2007, 72, 7.

3 a) Y. Hori, Y. Abe, M. Ezaki, T. Goto, M. Okuhara, M. Kohsaka, J. Antibiot. 1993, 46, 1055. b) Y. Hori, S. Takase, N. Shigematsu, T. Goto, M. Okuhara, M. Kohsaka, J. Antibiot. 1993, 46, 1063. c) Y. Hori, Y. Abe, M. Nishimura, T. Goto, M. Okuhara, M. Kohsaka, J. Antibiot. 1993, 46, 1069.

4 S. O. De Silva, M. Watanabe, V. Snieckus, J. Org. Chem. 1979, 44, 4802.

5 R. J. Mills, V. Snieckus, J. Org. Chem. 1989, 54, 4386.

6 R. J. Mills, N. J. Taylor, V. Snieckus, J. Org. Chem. 1989, 54,4372 .

7 N. Tahara, T. Fukuda, M. Iwao, Tetrahedron Lett. 2002, 43, 9069.

8 N. Tahara, T. Fukuda, M. Iwao, Tetrahedron Lett. 2004, 45, 5117.

9 ortho-Lithiation of 3 with $n$-BuLi in diethyl ether was originally reported by Gschwend and Hamdan, see: H. W. Gschwend, A. Hamdan, J. Org. Chem. 1975, 40, 2008. We observed the reaction of the ortho-lithio species derived from 3 with 1-iodopropane in diethyl ether was quite sluggish to give $\mathbf{5 a}$ in only $6 \%$ yield $\left(0^{\circ} \mathrm{C}, 4 \mathrm{~h}\right)$.

10 Y. Kurosaki, T. Fukuda, M. Iwao, Tetrahedron 2005, 61, 3289.

11 W. M. Pearlman, Tetrahedron Lett. 1967, 8, 1663.

12 A. T. Kreipl, C. Reid, W. Steglich, Org. Lett. 2002, 4, 3287.

13 C. E. Anson, C. S. Creaser, A. V. Malkov, L. Mojovic, G. R. Stephenson, J. Organomet. Chem. 2003, 668, 101. 